\title{
The Use of Films to Teach Vocabulary and Colloquial Expressions in the Eleventh Grade at Departamental "Tierra de Promision" Secondary School
}

Jairo A. Hoyos

Universidad Surcolombiana, Colombia jairohoyostheunitedkingdom@gmail.com

\section{Resumen}

Se extrajo algunas palabras y expresiones coloquiales de una película sobre la personalidad para diseñar algunas actividades y materiales durante todo el proceso de enseñanza: con el objetivo de motivar a los estudiantes a través de la película. Se administró la investigación-acción como un método para analizar todo el procedimiento de la implementación de la prueba piloto. Los resultados fueron bastante sorprendentes y extraordinarios, lo que demostró que es posible impactar a los estudiantes a través de esta estrategia. Los participantes de esta prueba piloto fueron los estudiantes del grado undécimo y se llevó a cabo en la institución educativa "Departamental Tierra de Promisión". El proceso de enseñanza de este proyecto que tomó todo el semestre de práctica docente en secundaria fue evaluado por algunos profesores del programa de Licenciatura en inglés de la Universidad Surcolombiana en el cual se concluyó que el uso de películas motiva a los estudiantes a aprender vocabulario y expresiones coloquiales en la clase de inglés. (Cabe agregar que estos profesores del programa otorgaron un reconocimiento como "mejor practicante" al docente en formación por su desempeño con este proyecto). 


\section{Introduction}

I implemented an innovation project at a public school named Departamental "Tierra de Provision" Secondary School. This Secondary School is a huge institution which provides the students a well-documented library which has its own resources such as computers, video beams, a TV set, etc. Every section of the school which deals with a particular field of knowledge has its own audio visual room.

I previously extracted some words and colloquial expressions from a film about personality in order to design some activities during the whole process of implementing the project to motivate the students through the movie. What is highly relevant to highlight is that students from state schools do not have a really high level of English. However, there are some groups for whom English is being emphasised which denotes that their English lessons last more hours and are more demanding. Students from the eleventh grade were the participants of this pilot study. They were 1104 and 1105. Half of the 1104's students is part of the program of English which prepares students to be more skilful in the foreign language. Therefore, I only carried out this pilot experiment with the ones that are not included in the English Program. They were 15 students from 1104 and 26 students from 1105. Most of the students are in their late teens and are generally girls.

I did not carry through with this pilot experiment by including extra hours; it was carried out during the English lessons within six sessions. Each session took about one or two hours. There were different activities and exercises in the lessons but the most noteworthy objective was watching the whole film. The 1105's students had more chances to go through the whole process successfully rather than the 1104's students who were not able to have a continuum process due to many interruptions from the government that suspended the lessons of public schools for a period of time.

Students were found highly motivated to learn English through this project. Surveys, observations and exercises marked showed outstanding results which proved how successfully this pilot project was. Students advised me to continue working on this innovative, creative and didactic method to learn this language. They said they learned new vocabulary and colloquial expressions as well.

\section{Diagnosis}

Before I started the practicum process, I made some observations on a couple of English lessons which were taught by the cooperative teacher. It was quite noticeable that the students were learning English from a traditional method that was only taking into account the course book. The only resource that was being used was a tape-recorder to practice listening activities. I could observe that the teacher was not using the audiovisual room to watch videos or films in English with his students. They needed to be involved with games and films in the English class. In fact, I carried out a survey the first week I started teaching English.

Not only did I apply the survey for the students but I designed another one for the cooperative teacher. The teacher from the eleventh grade just answered the yes \& no questions. The cooperative teacher reported that he has been working as an English teacher for thirty-two years. He did a Bachelor's degree in Spanish. He does not even have any professional background in English but that is his responsibility which was laid on him by the state school. He reported in the survey that the school does not have enough resources to teach vocabulary and colloquial expressions through the use of films. He confirmed that he hardly ever teaches through the use of films. He also thinks that it is really important to design material using films to teach English.

Regarding the information gathered from the students, the cooperative teacher and the observations, the data is going to be triangulated; First, I am going to come up with a brief summary of the outcome from the questions administered in the surveys. The first question was about what the students do like most from their English lesson. $25 \%$ said they liked 'nothing' and $16.6 \%$ said it was 'enjoyable'. We could say that most of the students were not emotionally committed to the 
to the lesson because according to them there was nothing that they did like.

Second, I enquired what specifically the students do not like from their English lesson. The highest percentage (38\%) demonstrated that the lessons were 'monotonous' and 'boring'. They used to fall asleep during the lesson. The English lesson was not didactic, the exams were almost the same ones and the English teacher did not encourage them. Even though, 19.4\% said they did not like anything from the lesson. During the observation, I could notice that students were not quite concentrated on what the teacher was trying to teach them. Some of them were not paying attention to the lesson at all. This is what could be reflected in the survey, students were not really focused on the English lesson because they lacked motivation. The results showed that most of them agreed that the class was boring and monotonous.

Third, there was another question which was designed to know what the students would suggest to improve the teaching methodology in the English lesson. 44,4\% agreed that it would be a great idea to bring 'games' and activities to make the class more 'didactic' and $44.4 \%$ claimed that they would like to do exercises that include word squares, listening to songs, watching 'films' and 'videos' to improve their 'vocabulary' acquisition to make the lessons more didactic as well. It is really interesting to see the vast majority of the students to support the idea of bringing innovation to the class especially when it requires teaching them through the use of films.

Fourth, I wanted to know if the school had enough material to learn vocabulary and colloquial expressions. $56 \%$ of the students answered "no". The cooperative teacher agreed as well. Due to the previous outcome, it is highly probable that this state school does not provide this kind of material. Another question raised was regarding if the school had enough material to learn English in general through films. 77,77\% of the students answered "no". This was the same answer from the official English teacher. It is down to earth to say that the school does not supply for material to teach through films.

Fifth, the students were asked regarding the frequency that their English teacher does use films in the lessons. $69,44 \%$ of the students answered that they had 'never' been taught through films and $0.0 \%$ of the students confirmed that they had 'always' been taught through films. According to the teacher; he had 'hardly ever' used the previous resource in his lessons. It is quite clear to understand that more than half of the students agreed that they had 'never' been taught through films. In addition to this, the teacher agreed to this response.

Finally, 97,22\% of the students said that they would suggest to design material to teach vocabulary and colloquial expressions through the use of films. The cooperative teacher said so as well. 19,44\% reassured that they would like to practice 'listening' through the use of 'films'. They also mentioned they would like to learn vocabulary and a new English accent. Another 19,44\% answered that they wanted to be 'encouraged' by bringing to the classroom 'new ideas' to make the lesson more 'interesting'. The cooperative teacher said he would suggest so too.

Now, it's time to come up with the final conclusion for this survey. The humongous amount of students acknowledged that their English lessons were going through a dangerous road which stood for a downfall in their learning process. Their current English teacher was not bringing resources such as films to encourage them to learn vocabulary and colloquial expressions. Their English classes were quite monotonous and boring. The students needed that their new English teacher would bring innovation which blew them down and motivated them to learn the target language.

\section{Objectives}

\section{General Objective}

- Determine the impact of the use of films on the vocabulary learning process in the eleventh grade at Departamental "Tierra de Promision" Secondary School 


\section{Specific Objectives}

- Describe the impact that films may have on students' motivation in the English class.

- Determine if the tasks designed to work with films in the English class contribute meaningfully to the vocabulary acquisition.

\section{Literature Review'}

\section{Vocabulary}

Oxford and Scarcella (1994) agreed to say that teachers should encourage learners how to foster their vocabulary acquisition. Pupils need to learn new words using different vocabulary learning strategies instead of useless ways that are not pedagogical to acquire new vocabulary (p. 231).

\section{Colloquial Expressions}

Holmes (1992, p.265 in Barzegar 2008) "proposed that there are two important linguistic characteristics of colloquial style in English. They are pronunciation and grammatical features". McCrimmon (1963 in Barzegar 2008) says that "colloquial English is about short simple sentences, clipped words (cab, phone), few rhetorical devices, a generous use of contractions, omission of relative pronouns, simplified grammatical structure and a personal or familiar tone that gives the impression of speaking intimately".

\section{Authentic materials}

This type of material is not designed to learn a new language. However, the second language learner could take advantage of this material as it provides a real use of the language. Authentic use of the language could be found in magazines, newspapers, reports cards, phone messages, radio broadcasts, movies, and podcasts and so on (Ianiro, S., 2007, p.1).

\section{Teaching Vocabulary through films} According to Ahmed Khalid Al-Sarhan's thesis (2013, p. 20) about the effect of using movies in teaching vocabulary, he found out the difference between learners who are taught vocabulary by the traditional strategy and by using movies. The findings of the study showed that the students who were taught by the traditional strategy were not totally engaged to the class. However, the interaction of the students who were taught vocabulary by using movies was much better and their attention was higher.

\section{Methodology}

\section{Action Research}

According to Burns (2010), Action Research equips researchers with opportunities to progress in the investigation during every session. Kemmis and McTaggart (1988) give the details of the cycle of research naming each one as follows; planning, action, observation and reflection. The first phase of the research is called Planning. The participants are involved to describe what problems are affecting the specific context. After the issues are recognised, a plan of action is carried out to make improvements to the educational environment. The second phase is named Action. The researchers agree to decide the time of executing the plan into the teaching situation. Every session must be critically reported to find different ways of implementing the plan. The third phase is Observation. Despite carrying out the plan of action, the researcher must collect data through the use of research instruments such as surveys, interviews, journals and etc. to analyse the effects of implementing the plan. The last phase is Reflection. Not only collecting the data is a matter of importance but reflection upon concerning issues is quite vital for bringing improvement to the specific research context. The researcher must evaluate and give details to comprehend certain situations. If the objectives are not accomplished at the last phase which is Reflection, the researcher must go through the cycle of research over and over again until seeing satisfying outcomes. 
Research instruments: observations, tests and surveys.

\section{Programming}

Tabla 1. A brief description of the content of each session.

\begin{tabular}{|c|c|}
\hline $\begin{array}{l}\text { Session } 1 \text { (Two } \\
\text { lessons) } \\
\text { Pre-Teaching }\end{array}$ & $\begin{array}{l}\text { During the first lesson, I played a game with the students to } \\
\text { introduce key vocabulary that they would learn through the film. } \\
\text { This game consisted of dividing the group into two teams. They } \\
\text { had to listen to the teacher when he said the definition of a word } \\
\text { in English. The teacher could say a synonym as well for helping } \\
\text { them which word it was. The first team that wrote the word on } \\
\text { the whiteboard would win one point. } \\
\text { Then, I gave the list of the definitions of the vocabulary about } \\
\text { personality to the students and told them to write the words down } \\
\text { with their definitions on a sheet of cardboard for the next lesson. } \\
\text { Finally, I invited my students to watch the movie at home. } \\
\text { During the second lesson, I started with a game to encourage and } \\
\text { help the students be more engaged to the class. This game is called } \\
\text { Sentence Race. They reviewed some previous vocabulary through } \\
\text { the use of this game. I wrote down each word on two pieces of } \\
\text { papers. That means writing the word twice, once on each paper. } \\
\text { I organized the words into two bundles. I gave out the words to } \\
\text { each team. Every student had a word and both teams had the } \\
\text { same words. When I said one word out loud, one student from } \\
\text { each team had to stand up. As soon as they stood up, they had to } \\
\text { run to the whiteboard and write a sentence using the same word. } \\
\text { The winner was the one who wrote the sentence grammatically } \\
\text { correct. } \\
\text { Then, I gave the students the photocopy of the pictures about } \\
\text { the scenes of the film and told them to put the pictures in the } \\
\text { correct order of the film so that they could do it in no more than } \\
5 \text { minutes. After that, I told them to write the description about } \\
\text { the characters of the film. } \\
\text { Moreover, I asked the students to correct each other's descriptions } \\
\text { so that they could have feedback from their writing. Finally, I } \\
\text { told them to draw the movie characters with their names on their } \\
\text { notebook. }\end{array}$ \\
\hline $\begin{array}{l}\text { Session } 2 \\
\text { Pre-Teaching }\end{array}$ & $\begin{array}{l}\text { I began the session with a game to help the students be more } \\
\text { involved with the whole class. The following game was called } \\
\text { Charades. This game is similar to Pictionary. I divided the group } \\
\text { into two teams. They had to choose one student from the team. } \\
\text { These two students had to act out a word that they found in a } \\
\text { piece of paper. Each team had to guess what word their classmates } \\
\text { were trying to act out by turns. The team that had the chance } \\
\text { to guess more words than the other team was the winner. (The } \\
\text { words were about the topic learnt in the previous lessons). }\end{array}$ \\
\hline
\end{tabular}




\begin{tabular}{|c|c|}
\hline & $\begin{array}{l}\text { It was really essential to take the students to the audio visual room } \\
\text { so that they could watch some videos about the description of the } \\
\text { movie characters. Then, I showed the students and explained the } \\
\text { colloquial expressions they were going to learn through the film. } \\
\text { This game is named Speaking } W \text {. Game. } \\
\text { I divided the group into two teams. Each team had to pick up } \\
\text { a piece of paper from a bag on which they found the colloquial } \\
\text { expression. They also had to do a sentence orally using the } \\
\text { colloquial expression. Their time to guess was about } 20 \text { seconds. } \\
\text { The team that did the oral sentence without any mistake won one } \\
\text { point. } \\
\text { I gave the students the photocopy of the wordsquare so that they } \\
\text { could do it to reinforce the vocabulary learnt in the previous } \\
\text { lessons. }\end{array}$ \\
\hline $\begin{array}{lr}\text { Session } & 3 \\
\text { While-Teaching }\end{array}$ & $\begin{array}{l}\text { In the third encounter with my students, I collected the posters } \\
\text { (about the description of the movie characters and drawings) } \\
\text { and the book they had just created with the movie characters' } \\
\text { descriptions as well. } \\
\text { Furthermore, I worked on the exercise I designed to teach the } \\
\text { vocabulary and colloquial expressions through the film. I spent } \\
\text { some time giving the instructions about the activity and reading } \\
\text { the script from the first extract. I asked if there was a new word } \\
\text { for them in the script too. } \\
\text { Besides, I watched the extract from the film with them. I also } \\
\text { asked them if they needed to watch it again in order to fill in the } \\
\text { blanks. } \\
\text { Finally, I gave the students some feedback about the exercises. } \\
\text { Then, I asked the students to choose ten words from the exercise } \\
\text { in order to write a sentence with each one of them. I told them to } \\
\text { write these ten sentences on a sheet of paper. At the end of the } \\
\text { session, I let them know that they had to write a comment from } \\
\text { the lesson. The opinion had to do with their preferences of the } \\
\text { session; they had just attended in order to collect data from this } \\
\text { intervention. }\end{array}$ \\
\hline $\begin{array}{lr}\text { Session } & 4 \\
\text { While-Teaching }\end{array}$ & $\begin{array}{l}\text { In the fourth encounter with my students, I worked on another } \\
\text { exercise I designed to teach the vocabulary and colloquial } \\
\text { expressions through the film. I spent some time giving the } \\
\text { instructions about the activity and reading the script from the } \\
\text { second extract. I asked if there was a new word for them in the } \\
\text { script too. } \\
\text { Besides, I watched the extract from the film with them. I also } \\
\text { asked them if they needed to watch it again in order to fill in the } \\
\text { blanks. } \\
\text { Moreover, I gave the students some feedback about the exercise. } \\
\text { Then, I asked the students to choose ten words from the exercise } \\
\text { in order to write a sentence with each one of them. I told them to } \\
\text { write these ten sentences on a sheet of paper. At the end of the } \\
\text { session, I let them know that they had to write a comment from }\end{array}$ \\
\hline
\end{tabular}




\begin{tabular}{|c|c|}
\hline & $\begin{array}{l}\text { the lesson. The opinion had to do with their preferences of the } \\
\text { session; they had just attended in order to collect data from this } \\
\text { intervention. } \\
\text { Finally, I let the students know that they were going to be } \\
\text { evaluated about what they learnt during the previous lesson } \\
\text { (session 3). I gave the students material on which they could } \\
\text { practice their reading skill. The reading was about the summary } \\
\text { of the film. They had to bring the answers of the exercise, a short } \\
\text { paragraph describing the saddest or happiest moment of their lives } \\
\text { on their notebook and the summary of the film the next lesson as } \\
\text { well. }\end{array}$ \\
\hline $\begin{array}{l}\text { Session } 5 \\
\text { (two lessons) } \\
\text { Post-Teaching }\end{array}$ & $\begin{array}{l}\text { This fifth and the sixth sessions were quite crucial because the } \\
\text { students were going to be evaluated to check if they learnt or not. } \\
\text { This session consisted of two lessons. During the first lesson, I } \\
\text { checked the homework on which they had to bring the answers of } \\
\text { the reading exercise, a short paragraph describing the saddest or } \\
\text { happiest moment of their lives and the summary of the film on } \\
\text { their notebook as well. } \\
\text { Besides, I spent some time giving the instructions about the final } \\
\text { exam. Then, I watched another extract from the film with them } \\
\text { so that they could fill in the blanks. After that, I told the students } \\
\text { to do the reading section from the exam and to choose the order } \\
\text { of the scenes of the movie as well. } \\
\text { Finally, I asked the students to be prepared for the oral quiz which } \\
\text { was about talking regarding their personal life experience. } \\
\text { During the second lesson, I gave the students some time to work } \\
\text { in pairs so that they could be more prepared for the oral quiz. } \\
\text { Thereupon, I called one by one to do their oral quiz. } \\
\text { Soon after, I gave the students some information about the } \\
\text { preparation for the final session which would be held in two weeks. } \\
\text { I chose the actors who would perform the main characters from } \\
\text { the movie and delegated responsibilities to the students for the } \\
\text { decoration and other important details for the next session. } \\
\text { A short while later, I gave the students who were going to be the } \\
\text { actors their script so that they could learn it by heart as well. } \\
\text { I told them to be prepared for the next class because they were } \\
\text { going to rehearse. } \\
\text { Finally, I reminded the students that every kind of participation } \\
\text { in the event would be scored for the fourth term. }\end{array}$ \\
\hline $\begin{array}{l}\text { Session } 6 \\
\text { Post-Teaching }\end{array}$ & $\begin{array}{l}\text { Before the session started, I arrived quite early to the place where } \\
\text { the meeting was going to be held. I came with some of my students } \\
\text { to decorate the place and got every small detail ready for such a } \\
\text { great event. I gave the students some time to make up their faces } \\
\text { and dress up. I advised the students who were going to be in } \\
\text { charge of the event to make sure that everything was perfect for } \\
\text { the celebration of Movie Fun Fest. } \\
\text { The host and the hostess of the event were students who had been } \\
\text { really skilful in their learning process. There were some students }\end{array}$ \\
\hline
\end{tabular}




\begin{tabular}{|l|l|}
\hline who were going to show the books they created which contained \\
the description of the movie characters and the summary of the \\
film. Other students had to give a short introduction to show the \\
huge posters about the description of the movie characters and the \\
cardboards about the definition of each word they learned during \\
the whole process of the innovation plan. There were two sketches \\
and a Five-Minute Play Contest. The best one would win some \\
prizes. The juries were the co-operative teacher, a student from \\
ILEUSCO who travelled to Trinidad and Tobago for two years and \\
the supervisor who was in charge of evaluating the event. Finally, \\
there were some students who had to take pictures and record the \\
event to collect data in order to evaluate the whole procedure of \\
the innovation plan. Some other students had to hand out the \\
surveys so that the students could fill in at the end of the session.
\end{tabular}

\section{Findings}

From the beginning, I could see that the participants were quite motivated with the vocabulary games which were planned for the pre-teaching lessons. What is more, when they came to the audio visual room to watch the videos about the movie actors who were performing the voices of the characters from the film, they paid close attention to the videos because I started asking them some questions like what the movie characters' names were. However, I did notice when they were asked to draw the movie characters and to write down their descriptions that the students were stressed because they had too much responsibility and homework. Nevertheless, when the third and fourth sessions took place the students' attention was really focused on watching the extracts from the film because they had to do some exercises related to the movie. One of the downfalls from this project was that they had too many exercises to do. In spite of their disproval for the quantity of homework, most of them were able to be responsible for what they had to do. At the end of project, those who did not have high scores were added some extra points on their grades just because of their participation on the final session when they had to show what they had learnt during the whole project.

Chart 1. This bar chart describes the preferences of the students about the pilot experiment regarding the statements from the survey

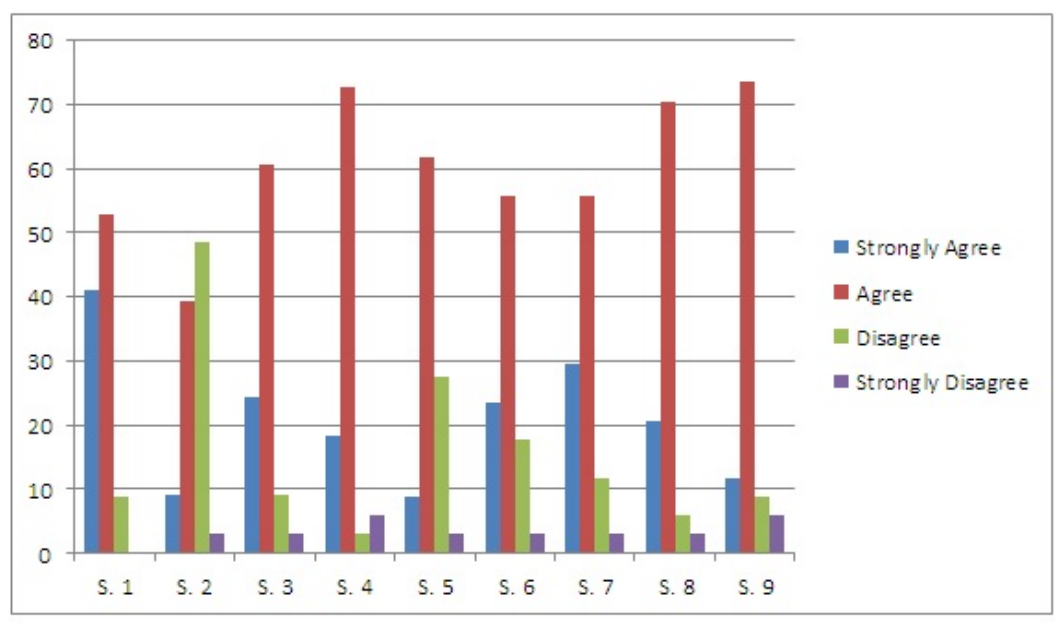




\section{Statement}

1. The film was interesting.

2. The types of exercises were challenging to me.

3. The film gave me the opportunity to understand the new words and expressions in a meaningful context.

4. The film enabled me to learn the meaning, spelling and pronunciation of the new words and expressions.

5. The different tasks did meet my expectations.

6. I had fun doing the wordsquare.

7. I felt motivated to use films to learn vocabulary and colloquial expressions.
8. I was able to write sentences using the vocabulary and colloquial expressions from the film.

9. The type of exercises enabled me to put the words and colloquial expressions into practice through my oral skill.

10. I can understand the meaning is for the words and colloquial expressions that I learnt through the film in a written text.

Chart 2. This bar chart describes the most common words of the participants' comments from the survey.

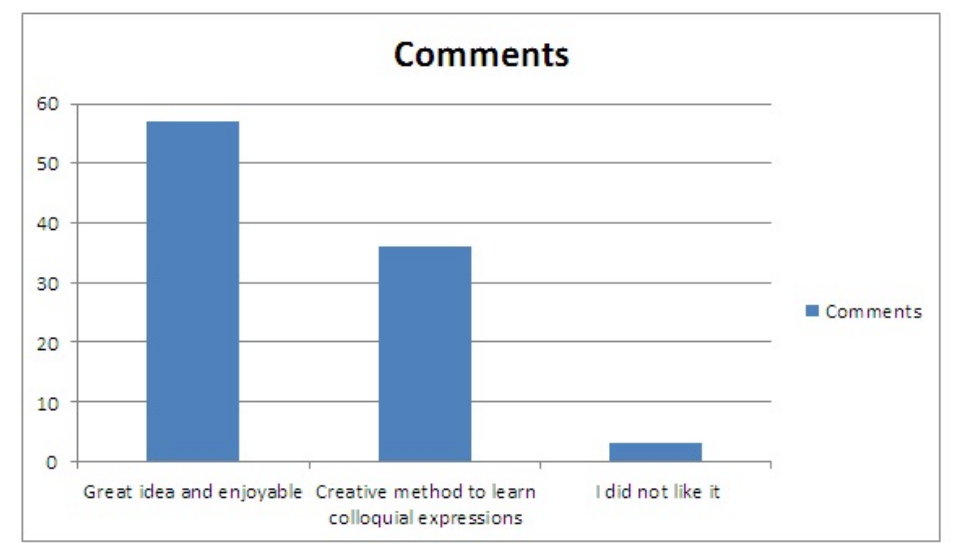

There was a section from the survey where the students could write their opinion. Only $41.1 \%$ of the students wrote it down. The most common words that the students used to express their likes and dislikes were "great idea", "enjoyable", "creative method to learn vocabulary" and "I did not like it". It is quite evidenced how these students showed their preferences through the surveys.

Furthermore, the cooperative teacher filled out a survey which had the same criteria from the survey of the students to evaluate this innovation plan as well. I am going to mention what the preferences of the cooperative teacher were. The cooperative teacher agreed that the film was interesting. He agreed that the types of exercises were challenging to the students. He agreed that the film gave the students the opportunity to understand the new words and expressions in a meaningful context. He agreed that the film enabled the students to learn the meaning, spelling and pronunciation of new words and expressions. He agreed that the different tasks did meet the expectations from the students. He agreed that the students had fun doing the wordsquare. He agreed that the students felt motivated to use films to learn vocabulary and colloquial expressions. He agreed that the students were able to write sentences using the vocabulary and colloquial expressions from the film. He agreed that the type of exercises enabled the students to put the words and colloquial expressions into practice through the oral skill and he also agreed that they could understand the meaning for the words and colloquial expressions that they learnt through the film in a written text.

Now, it is really substantial to triangulate the findings from the observations of the student teacher and the surveys from the students and the cooperative teacher. First, $52.94 \%$ of the students 
agreed that the film was interesting and so did the teacher. $41 \%$ of them also said that they strongly agreed. I could notice they were quite interested. This film did catch the attention of the students and did motivate them to learn more English using a meaningful method.

Second, $39.39 \%$ of the students agreed the types of exercises were challenging to them and the teacher also agreed but, $48.48 \%$ of them disagreed that the exercises were challenging. When the project was in the middle of the process, the students were annoyed because of the several activities they had to do in less time. It could be said that the type of activities was not quite difficult; the thing that concerned the students was that there were so many things to do.

Third, $39.39 \%$ of the students agreed that the film gave them the opportunity to understand the new words and colloquial expressions in a meaningful context. $24.24 \%$ of them strongly agreed and the teacher also agreed so. All of the students except for one restated that the film was successful in granting them the chance to understand unknown words.

Fourth, $72.72 \%$ of the students agreed that the film enabled them to learn the meaning, spelling and pronunciation of the new words and expressions. $18.18 \%$ of them strongly agreed and so did the teacher. More than half of the students acknowledged that they learnt vocabulary and colloquial expressions through the film. It was quite remarkable this result from this criterion. It is undeniable to say that the film helped the students to learn vocabulary and colloquial expressions.

Fifth, 55.88 percent of the students and the teacher agreed that they did feel motivated to use the film to learn vocabulary and colloquial expressions. $29.41 \%$ of them strongly agreed so. The vast of the students commented they did love the film and did feel motivated and advised the student teacher to bring such activities so that they could learn English through films.

Sixth, $61 \%$ of the students and the teacher agreed that they were able to use the knowledge learnt to write sentences. $26.47 \%$ of them strongly agreed so. Most of the students learnt how to write sentences using the words and colloquial expression extracted from the film about personality because it was reflected on the results of the exercises they did in the lesson.

Seventh, $70.58 \%$ of the students and the teacher agreed that the type of exercises enabled them to put into practice what they acquired in the lesson through their oral skill. $20.58 \%$ of them strongly agreed so. At the end of the project, some of them talked about a personal life experience in English.

Finally, $73.52 \%$ of the students agreed that they could understand the meaning for the words and colloquial expressions that they learnt through the film in a written text. Throughout the process, they reinforced the vocabulary and the colloquial expressions through the use of the film; they also had to read a paragraph which was about the summary of the film to answer the questions related to it. More than half of the students had a high average score in this activity. According to this, it could be said that they understood the meaning of the words quite well. The students also had to write a comment in the survey; $41 \%$ of the students wrote their comments. However, all of them except for $2 \%$ of them were positive comments about the project. If you look behind; the results from the surveys that the students and the teacher filled in were mostly positive. Not only the answers from the research instruments were quite impressive but the high scores that the students had at the end of the process of the project were so. The impact that the film had on the students' motivation in the English lesson was unmistakably successful because during the process of the while-teaching sessions, I asked the students to write some comments from the lessons and what they could suggest me to do on the following lessons and as a result, more than half of their opinions were positive. They also had some time to watch the whole movie at school and showed too much interest in the sessions. The tasks designed to work with films in the English lesson contributed meaningfully to the vocabulary 
acquisition. Regarding to the results of the surveys; the students had a really nice performance on learning the definitions with all the components which involve acquiring the knowledge they received from the film. However, the only pitfall was that there were so many tasks they had to do that they came to a point where they felt a little overburdened. Last but not least, the impact that the film made on the vocabulary learning process was remarkable and outstanding because all of the students except for the $2 \%$ of them were highly and extremely motivated to continue using this method to learn English.

\section{Conclusions}

The implementation of films in the language classroom does impact the students' vocabulary learning process. Films produce a positive influence to encourage the learners to grasp the meaning, pronunciation, spelling of new words and colloquial expressions. The use of films inside the classroom motivates the students to learn vocabulary and colloquial expressions. The different tasks that teachers design taking into account the students' perceptions, expectations are quite a lot helpful and creative for developing the students' vocabulary acquisition. The implementation of games activities contributes to reinforce the vocabulary acquisition of the students and allow the students to be more engaged with the film and the lesson.

\section{Recommendations}

As I mentioned before, the only pitfall from the pilot study was that there were too many activities in less time. I would recommend someone who would like to implement this research experiment to their English lesson not to design too much material and not to give them so much homework in one lesson because it could affect their motivation towards the lesson. They could feel overworked and bored. During the lesson, the teacher or the researcher should continually ask his or her students what they do think about the English lesson. The teacher should ask this kind of questions to the students to make them feel important and appreciated and the classroom's atmosphere would change completely. Last but not least, the teacher should not put too much pressure on the students because it would also affect their driving force to learn English.

\section{References}

1. Al-Sarhan, A. K. (2013). The Effects of Using Movies in Teaching Vocabulary (Master's thesis) (p. 17). The Kingdom of Saudi Arabia.

2. Barzegar, H., H., \& M. (2008). Translation of Colloquial Expressions in English-into-Persian Subtitled Films. Retrieved from http://www.translationdirectory.com/articles/article1541.php

3. Kemmis, S., McTaggart, R., 1988. Introduction: the nature of action research, In: Kemmis, S., McTaggart, R. (Eds.), The Action Research Planner, 3rd ed. Deakin University Press, Melbourne, Australia

4. Ianiro, S. (2007) Authentic materials. Professional development Fact sheet, No (1), American institute for Research

5. Oxford, R. L., \& Scarcella, R. C. (1994) Second language vocabulary learning among adults: State of the art in vocabulary instruction. System, 22(2), 231 
Appendix A

Peppa Pig Fun Fest

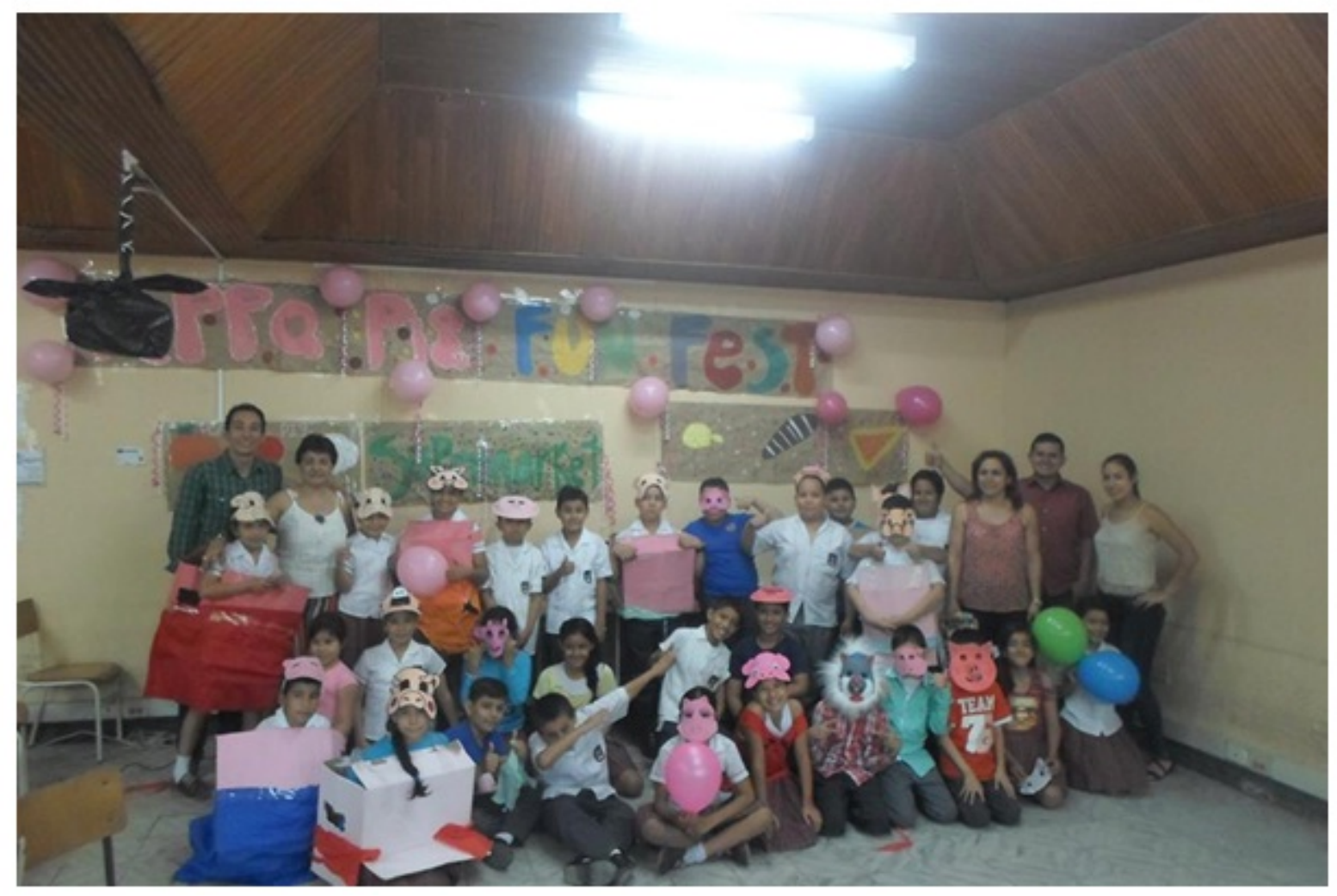

Poster Session (Primary School)

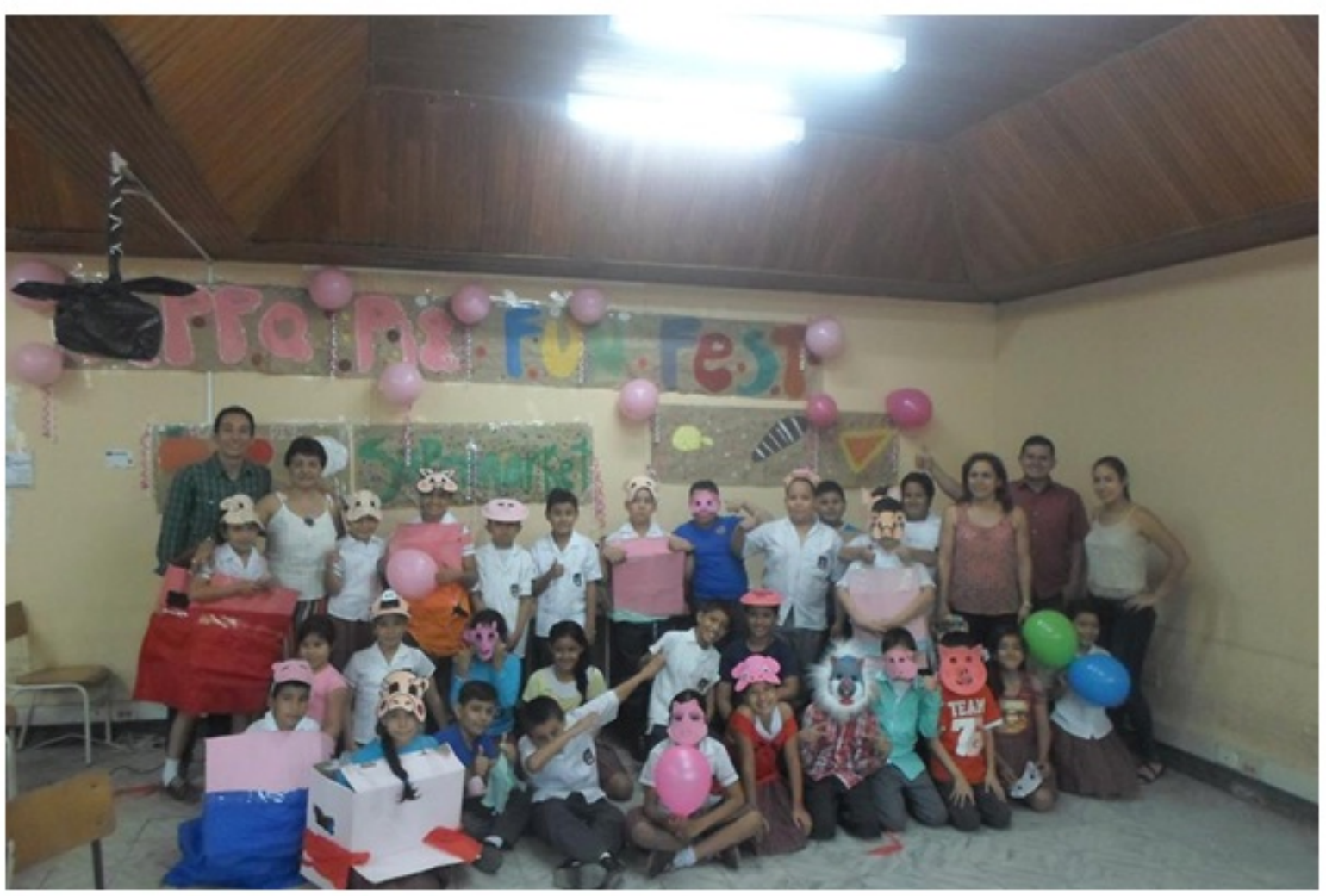

